\title{
Ultrastructural Changes during Sporulation of Clostridium pasteurianum
}

\author{
By B. M. MACKEY AND J. G. MORRIS \\ Department of Biochemistry, School of Biological Sciences, \\ University of Leicester, Leicester, LEI $7 R H$
}

(Accepted for publication 22 January 197I)

\begin{abstract}
SUMMARY
Rapid sporulation of a strain of Clostridium pasteurianum has been achieved in anaerobic batch culture, using a simple, defined medium containing only salts, glucose, L-cysteine and ammonium ions. Electron microscopy revealed that spore coat production preceded formation of spore cortex; both spore coat and exosporium were multilamellar structures, and the exosporium appeared to possess a central, basal pore. The production of a refractile spore from a vegetative cell took about 9 to $10 \mathrm{~h}$. at $35^{\circ}$; from septation to engulfment of the forespore took $\mathrm{I} \cdot 9 \mathrm{~h}$.; spore coat material appeared $2.9 \mathrm{~h}$. after engulfment, and spore cortex deposition commenced after a further $2.6 \mathrm{~h}$. Approximately $80 \%$ of the organisms produced mature, refractile spores. The various developmental stages occurred sufficiently synchronously to render the system amenable to future, correlative biochemical investigation.
\end{abstract}

\section{INTRODUCTION}

Electron microscopic studies of sporulating cultures of bacilli and clostridia have revealed the very similar sequence of morphological changes that lead to the creation, maturation and eventual release of spores in both genera (Murrell, 1967; Kay \& Warren, I968; Fitz-James \& Young, 1969; Walker, 1970). This sequence is divisible into seven easibly distinguished stages (Murrell, 1967), and in the case of the bacilli it has been possible to correlate these morphological changes with a number of simultaneous biochemical events (Warren, I968; Mandelstam, I969; Vinter, 1969). Very much less investigation of the sporulation process in the obligately anaerobic clostridia has been undertaken, largely because more complex sporulation media must generally be employed for these organisms (Perkins, 1965), their oxygen sensitivity complicates enzymic studies, and virtually no genetic study of them has as yet been made.

It was with a view to eventual biochemical study of the sporulation process in Clostridium pasteurianum that the present investigation was undertaken. This paper reports that rapid sporulation of this organism in relatively high yield is achievable in batch culture in a minimal, defined medium in which glucose remains the source of energy and the major source of carbon throughout. It has proved possible to time several of the major structural changes, and we conclude that the sporulation occurs sufficiently rapidly and near-synchronously to enable us to employ this system for correlative biochemical studies. 


\section{METHODS}

Organism. Clostridium pasteurianum (strain w-5) ATCC 60r3 was kindly supplied by Mrs Winifred Ego, University of Hawaii, Honolulu.

Maintenance. The organism was grown anaerobically at $37^{\circ}$ on $5 \mathrm{ml}$. slopes of defined growth medium solidified with $\mathrm{I} \cdot 5 \%$ agar (Oxoid, Ionagar no. I). Extensive sporulation occurred after about $48 \mathrm{~h}$. incubation and the sporulated slope cultures were then stored at $4^{\circ}$. The growth medium contained (per litre): $\mathrm{MgSO}_{4} \cdot 7 \mathrm{H}_{2} \mathrm{O}$, 0.I g.; NaCl, 0.I g.; $\mathrm{Na}_{2} \mathrm{MoO}_{4}$. $2 \mathrm{H}_{2} \mathrm{O}$, 0.0I g.; $\mathrm{CaCl}_{2}$, 0.0I g.; $\mathrm{MnSO}_{4} .4 \mathrm{H}_{2} \mathrm{O}$, 0.0I 5 g.; $\mathrm{NH}_{4} \mathrm{Cl}, 3.0 \mathrm{~g}$.; $\mathrm{CaCO}_{3}, 20.0 \mathrm{~g}$; ferric sodium sequestrate, 0.275 g.; glucose, 40.0 g.; biotin, $0.12 \mathrm{mg}$; $p$-aminobenzoate, $2.0 \mathrm{mg}$. It was sterilized by autoclaving at $\mathrm{I} 5 \mathrm{lb} /$ in. $^{2}$ for $\mathrm{I} 5 \mathrm{~min}$. and after cooling, $\mathrm{I} \cdot \mathrm{O} \mathrm{M}$-sterile potassium phosphate buffer, $\mathrm{pH} 7$ was added to a final concentration of $0.05 \mathrm{M}$.

Preparation of $a$ 'washed spore inoculum'. The organisms from a single sporulated slope culture were suspended in $5 \mathrm{ml}$. of sterile water. About $2 \mathrm{ml}$. of this suspension was held at $80^{\circ}$ for Io min. in a sterile, capped McCartney bottle, and was then quickly cooled to room temperature. One $\mathrm{ml}$. of this 'heat-shocked' spore suspension was aseptically inoculated into about $500 \mathrm{ml}$. of freshly autoclaved and cooled growth medium supplemented with $0.5 \mathrm{~g}$. L-cysteine $/ \mathrm{l}$. and contained in a $500 \mathrm{ml}$. Erlenmeyer flask stoppered with a 'Suba-Seal' rubber cap. The gas above the culture was replaced by oxygen-free $\mathrm{N}_{2}$ plus $\mathrm{CO}_{2}(95: 5, \mathrm{v} / \mathrm{v})$ via hypodermic needles inserted through this cap, and the culture was incubated at $37^{\circ}$ until maximum sporulation was obtained (about $48 \mathrm{~h}$.). The suspension of sporulated organisms was aseptically decanted from the bulk of the settled $\mathrm{CaCO}_{3}$ and was sedimented by centrifuging at $17,000 \mathrm{~g}$ for 20 min. at $2^{\circ}$. The harvested, sporulated organisms were twice washed in sterile distilled water and were resuspended in sterile water to yield a suspension containing approximately $10^{8}$ spores $/ \mathrm{ml}$. This 'standard spore suspension' was stored at $4^{\circ}$.

Experimental sporulation system. Five hundred $\mathrm{ml}$. of basal growth medium containing $0.25 \mathrm{~g}$. L-cysteine but without phosphate was sterilized by autoclaving at $\mathrm{I} 5 \mathrm{lb} /$ in. ${ }^{2}$ for $15 \mathrm{~min}$. in an Erlenmeyer flask. The flask and its contents were quickly cooled to $37^{\circ}$ and sterile I M-potassium phosphate buffer, $\mathrm{pH} 7$ was added to a final concentration of $0.05 \mathrm{M}$. The medium was immediately inoculated with $\mathrm{I} \mathrm{ml}$. of standard spore suspension (see above) which had immediately previously been heat-shocked at $80^{\circ}$ for Io min. The flask was capped with a Suba-Seal stopper and the gas space above the medium was filled with $\mathrm{N}_{2}$ plus $\mathrm{CO}_{2}(95: 5, \mathrm{v} / \mathrm{v})$. Growth usually commenced within I $5 \mathrm{~h}$. of the start of incubation at $37^{\circ}$, and the culture was then transferred to a sterile, anaerobic fermentation vessel $\left(600 \mathrm{ml}\right.$.) in which $\mathrm{pH}$ and $E_{\mathrm{h}}$ changes could be monitored and adjusted during continued incubation at $35^{\circ}$ in an atmosphere of $\mathrm{O}_{2}$-free argon. Samples of this culture were withdrawn at hourly intervals until sporulation was complete.

Electron microscopy. A sufficient volume of culture was centrifuged to yield a thin pellet of organisms (approx. $3 \mathrm{~mm}$. diameter). These were fixed and prestained for $2 \mathrm{~h}$. in a $0.5 \%$ solution of uranyl acetate in $\mathrm{pH} 6 . \mathrm{I}$ acetate-veronal buffer according to the method of Kellenberger, Ryter \& Śechaud (1958). The stained, fixed organisms were embedded in agar-solidified, acetate-veronal buffer ( $2 \%$ agar), the resulting block being cut to yield a cube of $0.5 \mathrm{~mm}$. side. The cube was now dehydrated by passage through a series of ethanol solutions of increasing concentration and was taken from 
absolute ethanol into a mixture ( $\mathrm{I}: \mathrm{I}, \mathrm{v} / \mathrm{v})$ of ethanol and araldite (CIBA (ARL) Ltd, Duxford). After overnight incubation at $40^{\circ}$ the cube was transferred to Araldite without accelerator and maintained at $40^{\circ}$ for $24 \mathrm{~h}$. before it was transferred to Araldite with accelerator in a 'Beem' capsule, which was then incubated on a slow rotary shaker for $48 \mathrm{~h}$. at room temperature. The araldite was then polymerized by 2 days incubation at $60^{\circ}$. Sections were cut with a diamond knife on a Tesla BS $490 \mathrm{~A}$ ultramicrotome, stained with lead citrate (Reynolds, I963) and examined in a Siemens Elmiskop I A electron microscope using an accelerating voltage of $80 \mathrm{kV}$ and an objective aperture of $50 \mu \mathrm{m}$.

Measurement of growth. Growth was followed turbidimetrically at $680 \mathrm{~nm}$. with a Unicam SP 600 spectrophotometer. Cell counts were made using a phase contrast microscope and an 'improved Neubauer' slide counting chamber.

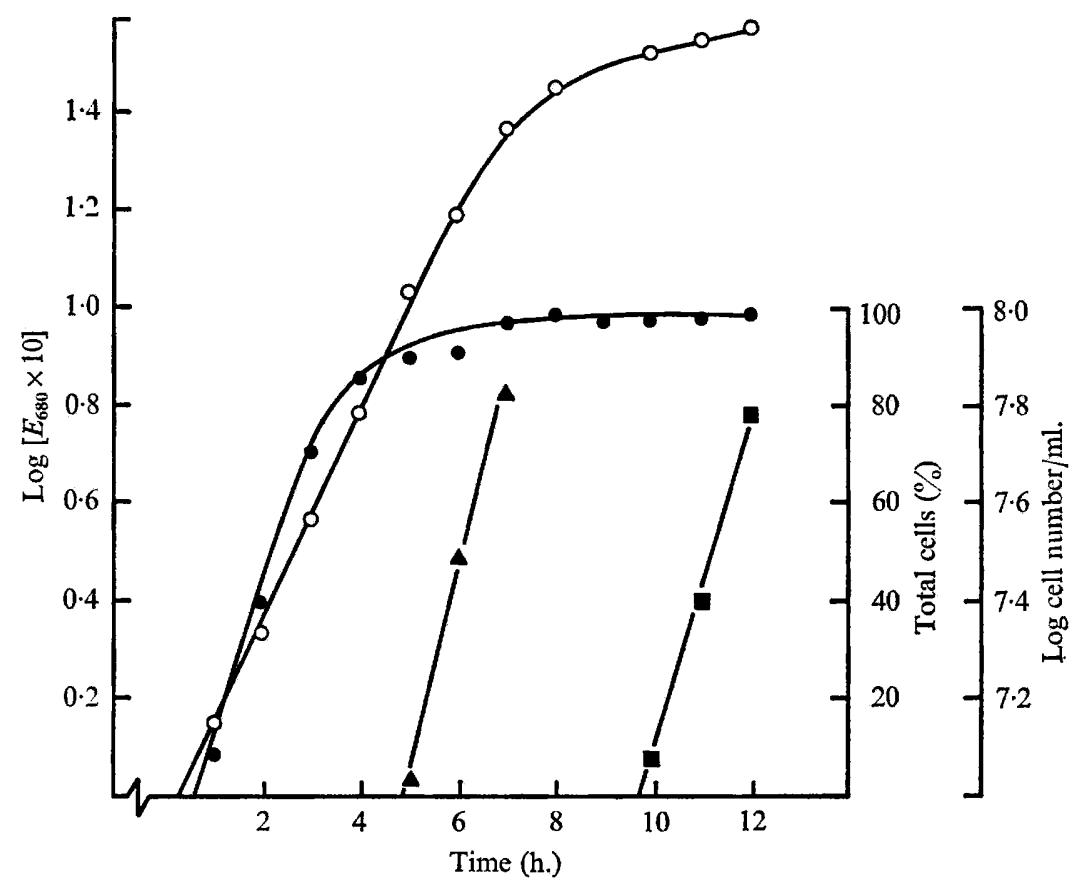

Fig. I. Growth and sporulation of Clostridium pasteurianum as observed by phase contrast microscopy. Extinction of the cultures at $680 \mathrm{~nm}$. (O) continued to rise after cessation of increase in cell number (๑). Phase-bright spores ( $\boldsymbol{\square})$ appeared approximately $5 \mathrm{~h}$. after the development of phase-dark forespores $(\boldsymbol{\Lambda})$.

\section{RESULTS}

Growth and sporulation in a chemically defined medium

Fig. I shows how the organisms proceeded to sporulate when growth ceased in a culture of Clostridium pasteurianum in the defined medium described in Methods. The absorbancy of the culture continued to increase for some 5 to $6 \mathrm{~h}$. after cell division had halted, but the first unequivocal sign of incipient sporulation seen by phase contrast microscopy was the formation of phase-dark forespores accompanied by a distinctive swelling of the mother cells. This stage was reached some $4 \mathrm{~h}$. after the 
virtual halting of cell multiplication; the transformation into phase-bright spores took another 5 to $6 \mathrm{~h}$. Over $80 \%$ of the total cell population proceeded to form mature spores.

\section{Ultrastructural changes during sporulation}

The sequence of anatomical changes seen to occur during sporulation of Clostridium pasteurianum is best discussed by reference to the seven easily distinguished developmental stages into which the sporulation sequence in other bacteria has already been divided (Fitz-James \& Young, I969). Our observations, described below and illustrated in Pl. I to 4, were made by electron microscopic examination of ultra-thin sections of organisms harvested at regular intervals during the course of sporulation.

Stage I: formation of an axial filament of chromatin. Sporulation is frequently presaged in both bacilli and clostridia by the condensation of the nuclear material of the organism into a central, 'axial' thread. In Clostridium pasteurianum, axial filament formation was only very rarely observed (Pl. I, fig. I), though it was looked for in many preparations of organisms harvested during the $4 \mathrm{~h}$. before septation (stage 2).

Stage 2: development of the forespore septum. Pl. I, fig. 2, 3 and 4 show the course of synthesis of the forespore septum whose formation was the first indication of sporulation in Clostridium pasteurianum. Invagination of the mother cell membrane close to one pole of the cell (Pl. I, fig. 2) was followed by ingrowth of the resulting annular septum; mesosomes were frequently associated with the ingrowing septum (Pl. I, fig. 3 and 4). The final, central fusion of the ingrowing membranes to create the forespore septum completely separated the forespore from the remainder of the spore mother cell (PI. I, fig. 4). The nuclear material trapped within the forespore was readily seen (Pl. I, fig. 4), but it was also at this stage that considerable deposition of closely packed globules of granulose occurred, obscuring structural details within the spore mother cell (Pl. I, fig. 2). Few of these globules were trapped within the forespore (Pl. I, fig. 4). No cell wall material was deposited between the two membranes of the forespore septum.

Stage 3: engulfment of the forespore. This process started with the forward projection of the mother cell membrane at the periphery of the forespore septum (Pl. 2, fig. 5). Localized extension of this membrane (which was again frequently observed to be associated with adjacent mesosomes) caused progressive engulfment of the forespore by the insinuation between cell wall and forespore membrane of mother-cell cytoplasm bounded on both outer and inner sides by new membrane. In sections this appeared as laterally advancing, finger-like projections of the mother cell (PI. 2, fig. 6) which eventually met and fused to completely engulf the forespore which then appeared to be embedded within the maternal cytoplasm (Pl. 2, fig. 7). By the time engulfment was complete, the cell had swollen to an ovoidal shape; the spore mother cell was packed with granulose, but some fine structure (including chromatin) was still visible within the forespore. Pl. 2, fig. 7 clearly shows the forespore's inner and outer membranes which at this stage were closely apposed. This developmental stage was easily recognized in the phase contrast microscope since, though the forespores were 'phasedark' the entire organisms were now 'phase-light' and their altered shape was very distinctive.

Stages 4 and 5: development of spore coat and spore cortex. Generally, in both bacilli 
and clostridia the spore cortex is deposited before the formation of the spore coat, and these processes represent stages 4 and 5 respectively in the normal course of sporulation (Murrell, 1967). However, in Clostridium pasteurianum these events occurred in reverse order, i.e. the spore coat was formed before the spore cortex.

The spore coat was produced as a series of separate fragments peripheral to the outer membrane of the forespore and easily identified in stained sections where they were electron-opaque (Pl. 3, figs. 8 and 9). These micrographs also quite clearly show the zone of electron-lucent material which separated the growing spore coat fragments from the outer membrane of the forespore; this zone was detectable before any coat fragments could be seen. Pl. 3, fig. 9 shows that considerable spore coat material has been produced before there was any significant deposition of cortical material between the inner and outer membranes of the forespore. 'Stacked' or layered structures were frequently found close to growing coat fragments (Pl. 3, fig. I I). Their significance is not clear, though it is tempting to attribute to them some role in the creation or assembly of coat material. While the mature spore coat ( $\mathrm{Pl}$. 4, fig. I5) was itself a multilayered structure with a repeat distance between layers of about $7 \mathrm{~nm}$., the interlayer distance in the 'stacks' was approximately II $\mathrm{nm}$.

In stage 4 of sporulation in Clostridium pasteurianum when the spore coat was being formed, the first signs of exosporium formation were also seen (Pl. 3, fig. 8) as a cleavage line (gap) arising just beneath the plasma membrane at the spore pole of the cell and extending downwards to the level of the base (i.e. mother cell end) of the spore. The deposition of cortical material between the inner and outer membranes of the forespore constituted stage 5 of sporulation in C. pasteurianum ( $\mathrm{Pl}$. 3, fig. 10); during this stage the spores themselves became phase-bright. Spore-coat formation was now well advanced, the precursor fragments having grown together and coalesced to produce a continuous, totally enveloping structure (Pl. 3, fig. IO). The cleavage line that was the first precursor of the exosporium was also evident in sections prepared during stage 5 (Pl. 3, fig. I0); magnification of a portion of this structure revealed that synthesis of the multilamellar exosporium was proceeding on its inner wall.

Stage 6: maturation. P1. 4, fig. I2 shows the completed spore surrounded by its exosporium but still within the spore mother cell. Synthesis of the spore cortex has been completed and little structural detail is now visible within the spore core. The region between spore and exosporium is markedly less electron-dense than the remainder of the spore mother cell, which could suggest that lysis commenced in this area.

Stage 7: lytic release of the mature spore within its exosporium. Terminal lysis of the mother cell with liberation of the mature spore was a protracted process; total conversion of a sporulated culture into a suspension of freed spores plus cell debris generally took several weeks of storage at room temperature. The coat of the liberated spore was 'sculptured' while the freed exosporium had ballooned out to yield the almost triangular outline first seen in the light microscope by Winogradsky (1902). These features are clearly shown in Pl. 4, fig. 13.

\section{Fine structure of the spore coat and exosporium}

Spore coat. A section of part of the mature spore coat is shown in high magnification in $\mathrm{Pl}$. 4, fig. I5. It was clearly a multilayered structure; in the section shown in Pl. 4, fig. I5, eight layers are discernible with an interlayer periodicity of approx. $7 \mathrm{~nm}$. In 
other sections between seven and ten layers were seen, each possessing a repeating subunit structure.

Exosporium. Like the spore coat, the exosporium of Clostridium pasteurianum was a multilayered structure; the repeat distance between layers was about $2.5 \mathrm{~nm}$. (Pl. 4, fig. I4), so that they were more closely packed than were those of the spore coat; the repeating subunit structure of each of these layers was even more obvious than that of the spore coat lamella, the repeat distance (centre to centre spacing) being $2 \cdot \mathrm{I} \mathrm{nm}$.

The exosporium was thickest at its apex (i.e. corresponding to the pole of the mother cell) and least thick at its base. This was due to some of its lamellae extending less far from the apex than others; the shorter lamellae were on the inside of the exosporium, suggesting that these were the last to be formed ( $\mathrm{Pl} .4$, fig. 13). In many longitudinal sections of the exosporium, both when liberated (Pl. 4, fig. I3) and when still contained within the spore mother cell ( $\mathrm{Pl} .4$, fig. 12 ), a pore remained in its base.

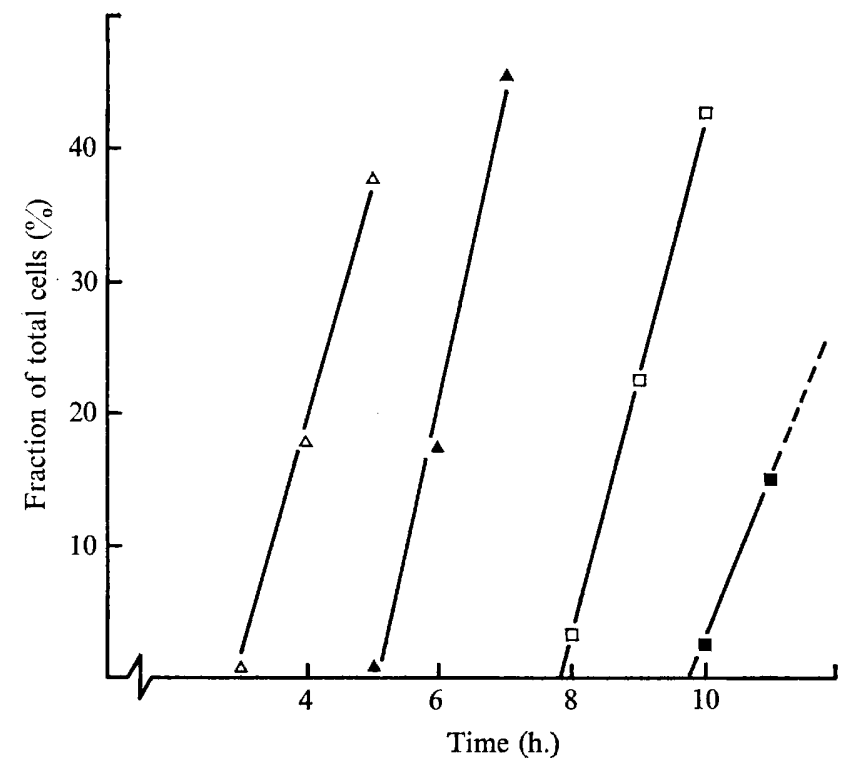

Fig. 2. Time course of events during sporulation of Clostridium pasteurianum estimated by 'direct' electron microscopy. Septation $(\triangle)$ was followed by complete engulfment of the forespore $(\boldsymbol{\Delta})$, initiation of coat formation $(\square)$ and the start of cortex deposition $(\square)$.

\section{Time scale of events during sporulation}

By direct examination of electron microscopic pictures of samples of cells withdrawn at regular intervals from the sporulating culture one can easily determine what proportion of the population has at any instant arrived at a given stage. How successfully one can employ this information to determine the time course of events during sporulation depends in large measure on the degree of synchrony exhibited by the sporulating culture (Dawes, Kay \& Mandelstam, I969). In the present study we found that nearly parallel straight lines were produced when the percentages of the population in various stages of sporulation were plotted against the time of incubation (Fig. 2). From this graph we concluded that, in the sporulation system employed for Clostridium pasteurianum, from septation to engulfment of the forespore took $\mathrm{r} \cdot 9 \mathrm{~h}$., 
spore coat material appeared $2 \cdot 9 \mathrm{~h}$. after engulfment, and spore cortex deposition commenced only $2 \cdot 6 \mathrm{~h}$. later than spore coat inception.

We also found that cessation of swelling of the mother cell and the appearance within it of a polar phase-dark area coincided with the completion of forespore engulfment. A progressive increase in refractility, readily observable by phase-contrast microscopy, was associated with the deposition of the spore cortex.

\section{DISCUSSION}

Since the first description of sporulation in Clostridium pasteurianum (Winogradsky, 1902) chemically complex media have been recommended for obtaining best sporulation of this organism (Bowen \& Smith, I955; Emzev, I963). Bowen \& Smith (1955) reported that sporulation would not take place if the $\mathrm{pH}$ of the medium were allowed to fall below $\mathrm{pH}_{5}$; they therefore buffered their ' $3 \%$ dextrose broth and $0.8 \%$ yeast extract medium' by adding $\mathrm{I} \% \mathrm{CaCO}_{3}$, a device previously recommended by Winogradsky (1902). In the present study we employed a defined, minimal sporulation medium incorporating $\mathrm{CaCO}_{3}$, but we have found that the $\mathrm{CaCO}_{3}$ may be omitted if the $\mathrm{pH}$ of the medium is controlled by the monitored addition during sporulation of sterile potassium carbonate solution (B. M. Mackey \& J. G. Morris, unpublished). This facilitates the harvesting and examination of the sporulating organisms.

The sequence of ultrastructural changes associated with sporulation in Clostridium pasteurianum possessed several distinctive features even though it generally resembled that observed in other sporulating bacteria (Ellar \& Lundgren, 1966; Kay \& Warren, 1968; Santo, Hohl \& Frank, 1969).

The infrequency with which we observed axial filament formation suggests that, at least in Clostridium pasteurianum, this might not be a necessary prelude to sporulation but might merely be an incidental consequence of cessation of DNA synthesis and cell division. One of the most surprising findings was that spore cortex was laid down in C. pasteurianum considerably later than the start of spore coat formation. As in other Clostridia, e.g. Clostridium pectinovorum (Fitz-James, 1962) and putrefactive anaerobe $3679 \mathrm{~h}$ (Santo et al. 1969), the spore coat first appeared as individual fragments which then coalesced to produce the entire spore coat. Unlike the developing spore coat of putrefactive anaerobe $3679 \mathrm{~h}$ which first appears at the base (i.e. mother cell end) of the forespore with subsequent fragments being added in a polar direction (Santo et al. 1969), the fragments of the spore coat in C. pasteurianum were from the outset randomly distributed about the forespore. The stacked, layered structures occasionally seen in association with coat fragments (Pl. 3, fig. II) could represent prefabricated coat material prior to its condensation. The late deposition of spore cortex enabled us to conclude that the acquisition of refractility was associated with cortex deposition rather than with coat formation. This is in keeping with the findings of Dawes et al. (1969) with Bacillus subtilis, and with the association of refractility with the synthesis of dipicolinic acid and uptake of $\mathrm{Ca}^{2+}$ ions by the forespore (FitzJames \& Young, 1969). Since the spore coats produced by many other bacteria are both chemically and anatomically heterogeneous (Kondo \& Foster, 1967), it was of interest that the spore coat of $C$. pasteurianum bore no appendages and was apparently an 'anatomically homogeneous, multilamellar structure (P1. 4, fig. I5). The spore coats of several bacilli have a laminated inner component, but this is generally covered 
by a distinctive outer coat (Walker, 1970), whilst microtubular appendages seemingly arising from the 'outer coats' of the spore are a feature of several clostridial spores (Hodgkiss, Ordal \& Cann, 1967).

The multilamellar exosporium of Clostridium pasteurianum resembled that of putrefactive anaerobe $3679 \mathrm{~h}$ (Santo et al. 1969) except that its outermost layer was devoid of the 'globular subunits' borne on the surface of the $3679 \mathrm{~h}$ exosporium. Again, although the exosporia of $C$. pasteurianum and of anaerobe $3679 \mathrm{~h}$ seemingly originate in a like manner, the completed exosporium of $C$. pasteurianum did not fragment to yield the parasporal pieces which were a feature of the $3679 \mathrm{~h}$ exosporium. Our discovery of a basal pore in medium, longitudinal sections of the exosporium of $C$. pasteurianum (Pl. 4, figs. $2_{2}$ and $\mathrm{I} 3$ ) needs to be substantiated by electron microscopic studies of the complete exosporium which make use of shadowing or freezeetching techniques, since this pore has not previously been reported as a feature of other exosporia. We were at first inclined to attribute the existence of this pore to aborted closure of the exosporium, or to rupture during sectioning of the structure at its weakest point. Yet the frequency with which we have seen the pore in sections suggests that it may be a normal feature of the exosporium of this strain of $C$. pasteurianum.

When Dawes et al. (1969) used a steady-state continuous-culture technique to measure the time taken to accomplish each of the major structural changes comprising sporulation in Bacillus subtilis, they found that in this system $6 \mathrm{~h}$. was required to produce a refractile spore from a vegetative cell. In our batch culture of sporulating Clostridium pasteurianum the same transformation took 9 to $\mathrm{Io} \mathrm{h}$. with comparable proportions of this time being expended in accomplishing the intermediate stages of forespore engulfment, coat and cortex production. Although, as is evident from Fig. 2, we did not achieve perfect synchrony of sporulating organisms in batch culture, we hope that this system will prove amenable to biochemical study.

We wish to thank Mrs Winifred Ego for supplying the organism, and we are indebted to Dr A. J. Rowe and Dr D. Kay for advice on electron microscopic procedures. This work was supported by a grant from the Science Research Council, and B.M.M. is the grateful recipient of a Scholarship from the Council.

\section{REFERENCES}

Bowen, J. F. \& Smith, E. S. (1955). Sporulation in Clostridium pasteurianum. Food Research 20 , $655-658$.

Dawes, I. W., Kay, D. \& Mandelstam, J. (1969). Sporulation in Bacillus subtilis. Establishment of a time scale for the morphological events. Journal of General Microbiology 56, I7 I-I 79.

Ellar, D. J. \& LundGren, D. G. (I966). Fine structure of sporulation in Bacillus cereus grown in chemically defined medium. Journal of Bacteriology 92, 1748-1764.

Emzev, V. T. (1963). U.O. Sporoobrazovanii Clostridium pasteurianum. Mikrobiologiya 32, 434-438.

FITZ-JAMES, P. C. (1962). Morphology of spore development in Clostridium pectinovorum. Journal of Bacteriology 84, 104-I I4.

Firz-JAmes, P. \& Young, E. (1969). Morphology of sporulation. In The Bacterial Spore, pp. 39-72. Edited by G. W. Gould \& A. Hurst. London: Academic Press.

Hodgkiss, W., ORdal, Z. J. \& CANN, D. C. (1967). The morphology and ultrastructure of the spore and exosporium of some Clostridium species. Journal of General Microbiology 47, 21 3-225.

KAY, D. \& WARren, S. C. (1968). Sporulation in Bacillus subtilis. Morphological changes. Biochemical Journal 109, 819-824. 
Kellenberger, E., RYter, A. \& Śechaud, J. (1958). Electron microscopic study of DNA-containing plasms. Vegetative and mature phage DNA as compared with normal bacterial nucleoids in different physiological states. Journal of Biophysical and Biochemical Cytology 4, 67I-678.

KonDO, M. \& FosteR, J. W. (1967). Chemical and electron microscope studies on fractions prepared from coats of Bacillus spores. Journal of General Microbiology 47, 257-27I.

Mandelstam, J. (1969). Regulation of bacterial spore formation. In Symposia of the Society for General Microbiology 19, 377-402.

MurRell, W. G. (1967). The biochemistry of the bacterial endospore. In Advances in Microbial Physiology, vol. I, pp. 133-251. Edited by A. H. Rose \& J. F. Wilkinson. London: Academic Press.

Perkins, W. E. (1965). Production of clostridial spores. Journal of Applied Bacteriology 28, I-I6.

ReYNolds, E. S. (1963). The use of lead citrate at high $\mathrm{pH}$ as an electron-opaque stain in electron microscopy. Journal of Cell Biology 17, 208-212.

Santo, L. M., Hohl, H. R. \& Frank, H. A. (1969). Uitrastructure of putrefactive anaerobe $3679 \mathrm{~h}$ during sporulation. Journal of Bacteriology 99, 824-833.

VinTER, V. (1969). Physiology and biochemistry of sporulation. In The Bacterial Spore, pp. 73-I23. Edited by G. W. Gould \& A. Hurst. London: Academic Press.

WALKER. D. (1970). Cytology of spore formation and germination. Journal of Applied Bacteriology 33, I-I 2.

WARREN, S. C. (1968). Sporulation in Bacillus subtilis. Biochemical changes. Biochemical Journal 1o9, $8 \mathrm{II}-8 \mathrm{I} 8$.

WINOGRADSKY, S. (1902). Clostridium pastorianum, seine Morphologie und seine Eigenschaften als Buttersäureferment. Zentralblatt für Bakteriologie, Parasitenkunde, Infektionskrankheiten und Hygiene (Abteilung II) 9, 43.

\section{EXPLANATION OF PLATES}

Electron micrographs of ultra-thin, lead citrate-stained sections of sporulating Clostridium pasteurianum. Symbols: $\mathrm{C}=$ coat (spore), $\mathrm{Cx}=$ cortex (spore), $\mathrm{Ex}=$ exosporium, $\mathrm{G}=$ granulose, $\mathrm{IM}=$ inner membrane, $\mathrm{M}=$ mesosome, $\mathrm{N}=$ nuclear material, $\mathrm{OM}=$ outer membrane, $\mathrm{P}=$ pore (exosporial), $\mathrm{S}=$ forespore septum, $\mathrm{Sp}=$ spore. Bar markers represent $0.2 \mu \mathrm{m}$. unless otherwise stated.

\section{Plate I}

Fig. I. Condensation of nuclear material in an axial filament.

Fig. 2. Initiation of septation by invagination of cell membrane (arrowed).

Fig. 3. Progressive inward growth of septum (arrowed).

Fig. 4. Completion of forespore septum.

Fig. 5. Onset of engulfment (arrowed).

Plate 2

Fig. 6. Mid-engulfment.

Fig. 7. Completion of engulfment with creation of forespore inner and outer membranes.

Plate 3

Fig. 8. Deposition of coat fragments and appearance of the 'cleavage line' (arrowed) that is the prelude to formation of the exosporium.

Fig. 9. Detail of coat deposition showing the electron-lucent zone (broken arrow) between the outer membrane of the forespore and the coat fragments. Bar marker $=50 \mathrm{~nm}$.

Fig. 10. Cortex deposition between inner and outer membranes of the spore.

Fig. I I. Detail of coat synthesis showing 'stacked structure' often seen in association with enlarging coat fragments. Bar marker $=50 \mathrm{~nm}$.

\section{Plate 4}

Fig. I2. Mature spore with exosporium still within spore mother cell. Bar marker $=\mathrm{I} \mu \mathrm{m}$.

Fig. 13. Liberated spore within its inflated exosporium.

Fig. 14. Detail of exosporium showing repeating subunit structure of its lamellae. Bar marker $=$ $50 \mathrm{~nm}$.

Fig. 15. Detail of spore coat. Bar marker $=50 \mathrm{~nm}$. 

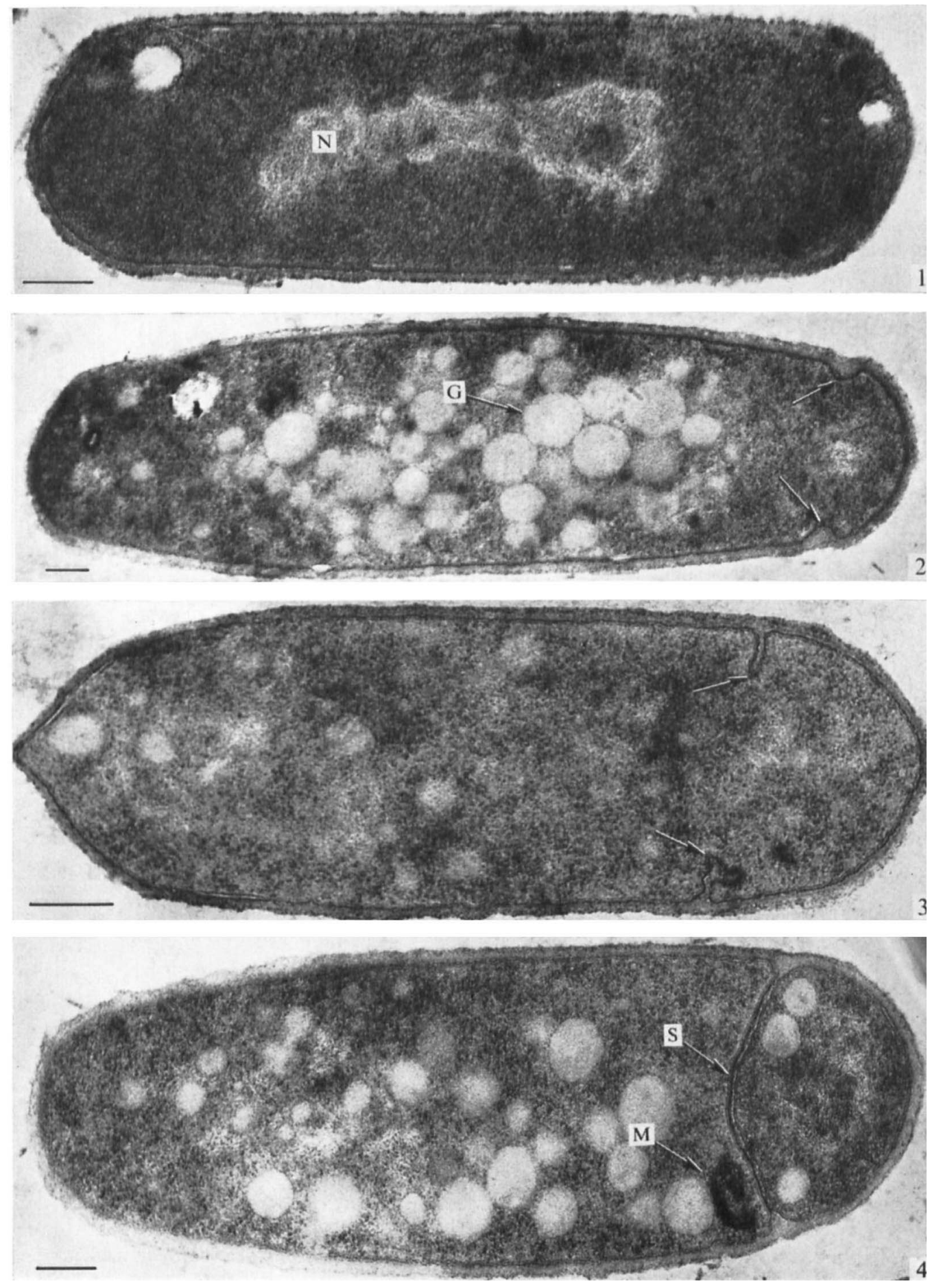

Plate I 

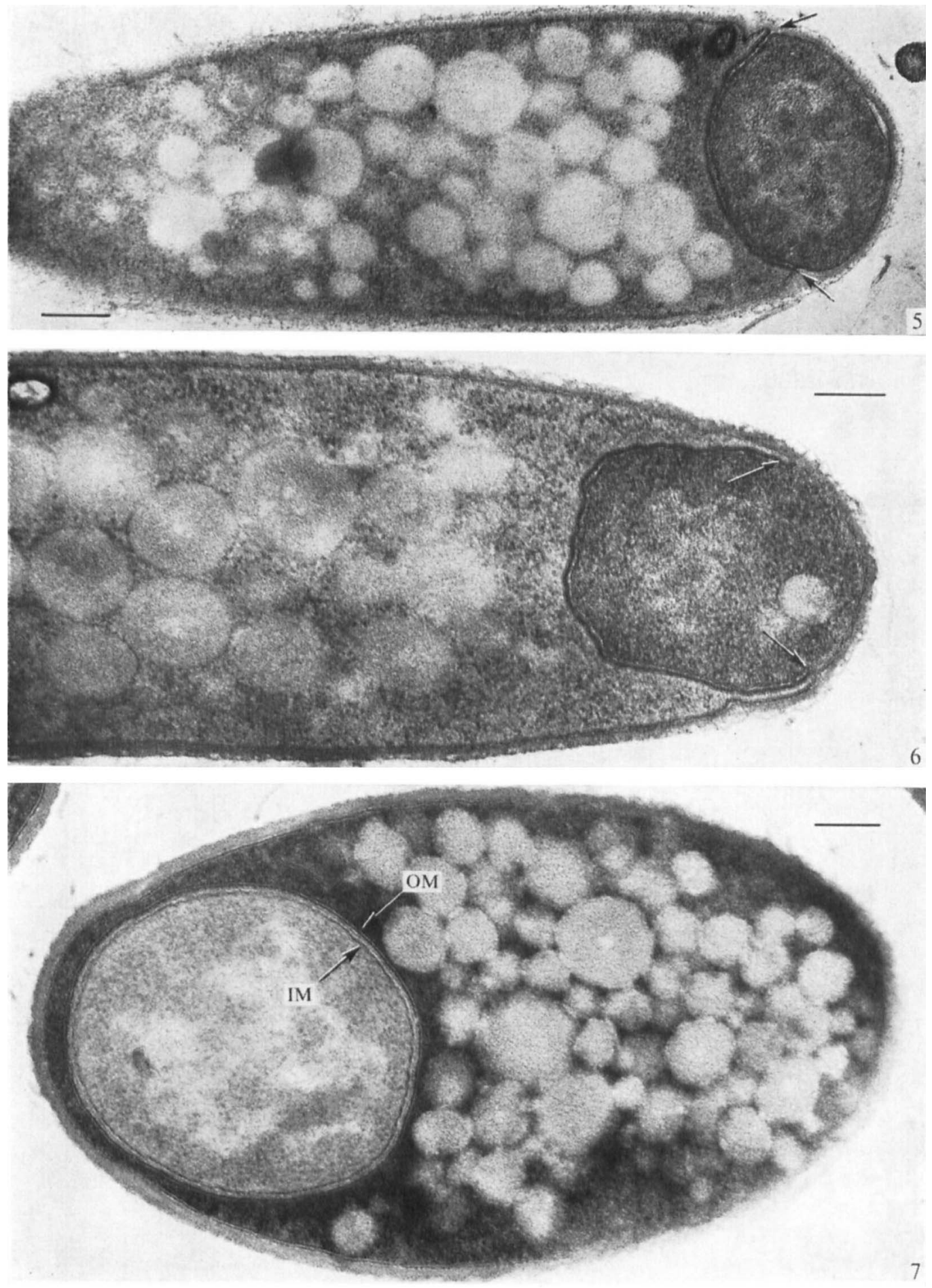

Plate 2 

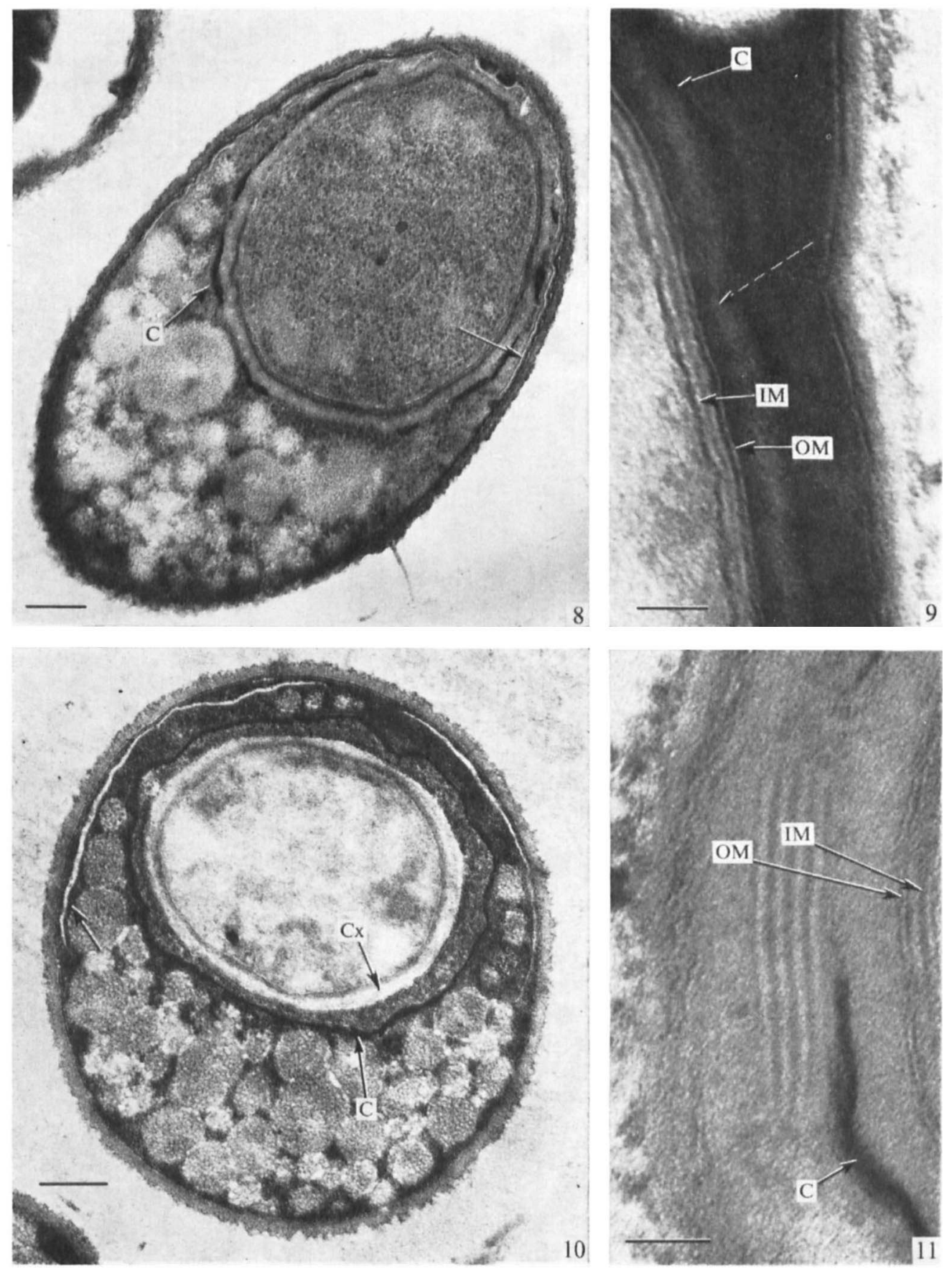

Plate 3 

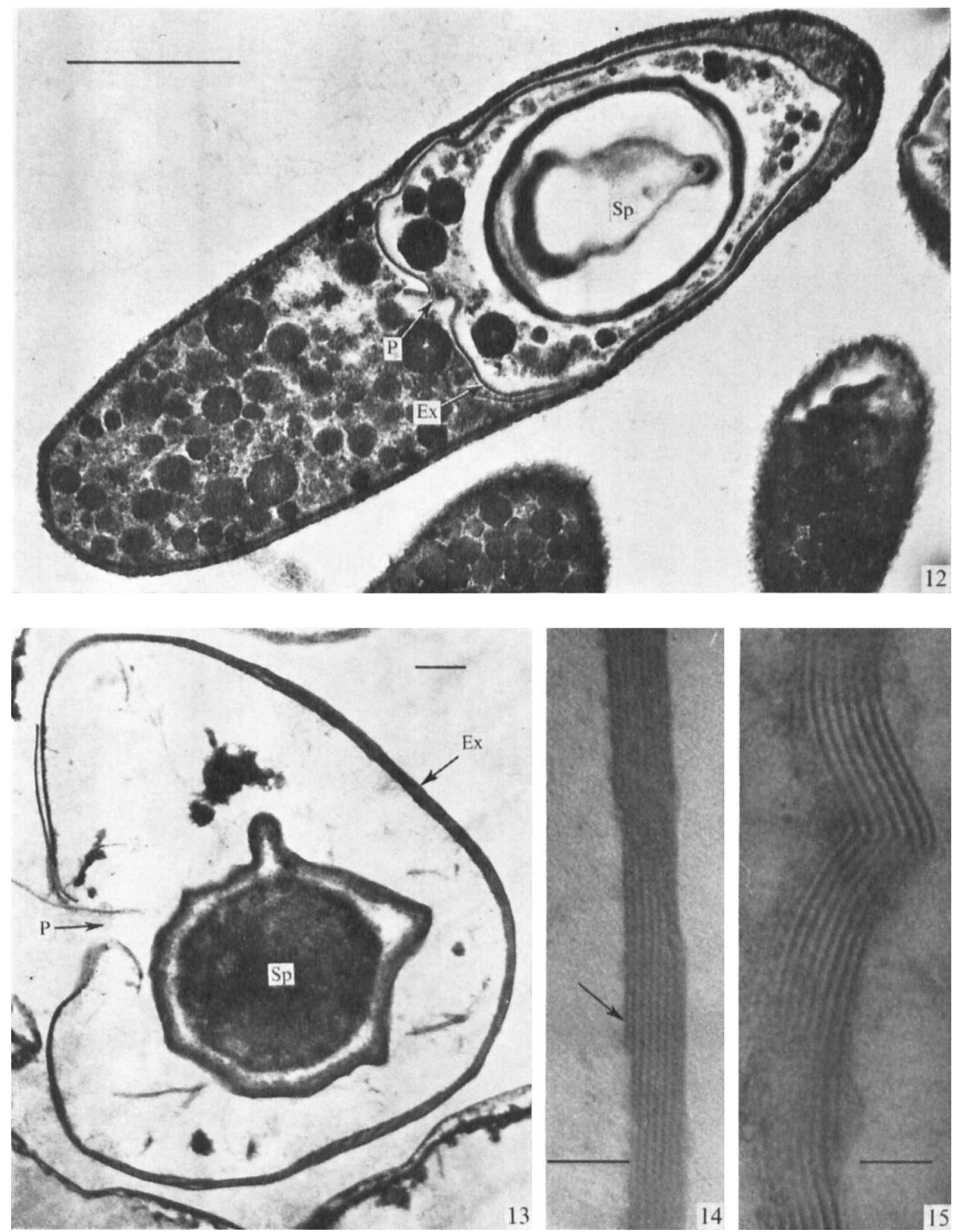

Plate 4 